\title{
BIODIVERSITAS KAPANG PADA PROSES BIODETERIORASI BATUAN CANDI BOROBUDUR
}

\section{BIODIVERSITY OF MOULDS IN THE BIODETERIORATION PROCESS OF BOROBUDUR TEMPLE}

\author{
Retna Munawati ${ }^{1}$, Bernadetta Octavia ${ }^{2}$, Nahar Cahyandaru $^{3}$ \\ 'Mahasiswa Program Studi Biologi Universitas Negeri Yogyakarta, Indonesia. \\ ${ }^{2}$ Dosen Program Studi Biologi Universitas Negeri Yogyakarta, Indonesia. \\ ${ }^{3}$ Pamong Budaya Ahli Madya Balai Konservasi Borobudur, Indonesia. \\ retnamunawati.2017@student.uny.ac.id
}

\begin{abstract}
ABSTRAK
Penelitian ini bertujuan untuk mengetahui keanekaragaman kapang yang dapat menyebabkan biodeteriorasi pada batuan Candi Borobudur dan jenis kerusakan yang ditimbulkan. Penelitian ini merupakan penelitian deskriptif kualitatif. Metode yang digunakan pada penelitian ini adalah metode purposive sampling, dengan kriteria sampel : batuan candi yang menampakkan spora atau miselium kapang, serta menampakkan kerak berwarna putih atau putih kekuningan. Metode pengambilan sampel dengan metode swab dan metode kerik. Inokulasi kapang menggunakan metode streak plate pada media CDA. Hasil penelitian berupa data kualitatif meliputi karakterisasi makroskopis dan mikroskopis. Hasil karakterisasi kemudian diidentifikasi dengan metode profile matching menggunakan buku acuan identifikasi kapang. Berdasarkan hasil identifikasi, terdapat 5 genus kapang yang ditemukan pada batuan Candi Borobudur yaitu genus Paecilomyces (67,5\%), Cladosporium (11,25\%), Penicillium (11,25\%), Aspergillus (8,75) dan Mucor (1,25\%). Jenis biodeteriorasi yang terjadi pada batuan candi diantaranya adalah adanya perubahan warna pada permukaan batuan candi yang menampakkan kerak berwarna putih maupun putih kekuningan dan pembentukan biofilm.
\end{abstract}

Kata kunci : Biodeteriorasi; Kapang; Batuan Candi Borobudur

\section{ABSTRACT}

The purpose of this research is to find out the mould diversity that can cause biodeterioration in the Borobudur Temple's rock, and the type of damage it caused. The research is qualitative descriptive. The method used in this research is purposive sampling method, with sample criteria: temple rock that shows spores or mycelium, and shows a white or yellowish white crust. The sampling method used was swab and chisel method. Inoculation of mould using the streak method on CDA medium. The results of research was qualitative data include microscopic and macroscopic characterization. The results of characterization were then identified using the profile matching method using the mold identification reference book. Based on the identification results, there are 5 genus of mold found in the rocks of Borobudur Temple, namely genus Paecilomyces $(67,5 \%)$, Cladosporium (11,25\%), Penicillium (11,25\%), Aspergillus (8,75) and Mucor (1,25\%). Types of biodeterioration on the rock temple are change in color on the surface of the temple rocks which looks a white or yellowish white crust, biofilm formation.

Keywords : Biodeterioration; Molds; Rock of Borobudur Temple 


\section{PENDAHULUAN}

Candi Borobudur merupakan salah satu warisan cagar budaya Indonesia yang terletak di daerah Borobudur, Magelang, Jawa Tengah. Candi Borobudur adalah salah satu monumen Budha terbesar di dunia dan termasuk dalam daftar warisan dunia dari UNESCO sejak tahun 1991 (UNESCO Office, 2013). Sebagai warisan dunia, Candi Borobudur memiliki pengaruh yang luar biasa terhadap popularitas wisata di dalam maupun di luar negeri karena Candi Borobudur tidak hanya digunakan sebagai tempat peribadatan umat budha. Namun, Candi Borobudur juga dimanfaatkan sebagai tempat wisata, kebudayaan, pendidikan dan ilmu pengetahuan. Oleh karena itu menjaga kelestarian Candi Borobudur merupakan hal penting, terutama dari kerusakan batuan candi yang dapat mengurangi nilai estetika Candi Borobudur.

Kondisi Candi Borobudur yang berada pada tempat terbuka dan tanpa atap memungkinkan permukaan batu candi berinteraksi langsung dengan lingkungan di sekitarnya, sehingga lebih rentan mengalami kerusakan. Selain itu jenis batuan penyusun Candi Borobudur juga berpengaruh terhadap proses kerusakan batuan candi. jenis batuan penyusun Candi Borobudur merupakan batu andesit, batu jenis ini memiliki tingkat porositas yang tinggi sehingga batuan lebih mudah dipahat, namun karena porositas tinggi tersebut, andesit penyusun Candi Borobudur memiliki kuat tekan yang tergolong rendah jika dibandingkan dengan batuan sejenis sehingga lebih mudah mengalami kerusakan.

Menurut Siregar (2011), proses kerusakan dan pelapukan yang terjadi pada batu penyusun Candi Borobudur dapat dikelompokkan dalam 4 macam, yaitu kerusakan mekanis, pelapukan fisik yang disebabkan oleh cahaya, kelembapan, cuaca, suhu, penguapan yang dapat meneybabkan terjadinya pengelupasan batuan, pelapukan kimia dan pelapukan biologis yang disebabkan oleh agen biologi seperti mikroorganisme.

Kapang merupakan salah satu mikroorganisme yang dapat menyebabkan kerusakan pada batuan candi. Kapang memiliki potensi deteriogen yang lebih besar daripada bakteri karena dapat memproduksi dan mengeluarkan konsentrasi asam organik yang lebih tinggi. Kapang tersebut dapat mengeksresikan asam organik seperti asam oksalat dan asam sitrat sehingga dapat melepaskan kation metabolik dari permukaan batu. Selain itu, hifa kapang dapat menembus permukaan batu hingga bagian bawah sehingga menyebabkan kerusakan. Penetrasi batuan yang dilakukan oleh hifa jamur dapat menyebabkan proses pengangkutan air, senyawa organik, dan nutrisi melalui batu, sehingga dapat memfasilitasi kolonisasi interior bakteri (Christopher dan Mitchell, 2005).

Kapang juga merupakan mikroorganisme yang berperan dalam pembentukan biofilm pada permukaan batuan candi. kapang juga dapat bersimbiosis dengan cyanobacteria dan membentuk lichen yang juga dapat melapukkan batuan. Menurut Habibi (2020), Lichen merupakan simbiosis dari jamur organisme sumber carbon seperti cyanobacteria maupun alga. Sekitar 98\% simbiosis tersebut terdiri dari jamur. Oleh karena itu perlu dilakukan identifikasi dan karakterisasi kapang yang menyebabkan biodeteriorasi pada batuan Candi

\section{METODE}

Penelitian dilakukan pada bulan November 2020 - Januari 2021 di Laboratorium Biologi Balai Konservasi Borobudur. Subjek pada penelitian ini adalah kapang yang diisolasi dari batuan Candi Borobudur yang mengalami kerusakan. Jenis penelitian ini adalah deskriptif kualitatif. Teknik pengambilan sampel yang digunakan adalah teknik purposive sampling, yaitu teknik penentuan sampel dengan syarat atau kriteria tertentu. Kriteria sampel pada penelitian ini yaitu : batuan candi yang menampakkan spora atau miselium kapang, serta menampakkan kerak berwarna putih atau putih kekuningan. 


\section{Prosedur Penelitian}

Prosedur pada penelitian ini yaitu : pengambilan sampel, yang dilakukan pada lorong II sisi selatan, utara dan timur Candi Borobudur yang ditumbuhi kapang yang menampakkan kerak berwarna putih kekuningan. Sterilisasi alat dan media, pembuatan medium untuk menumbuhkan kapang, isolasi kapang, subkultur kapang dan karakterisasi kapang.

\section{Teknik Pengumpulan Data}

Teknik pengumpulan data diperoleh dari pengamatan kapang secara mikroskopis dan makroskopis serta identifikasi kapang. Pengamatan makroskopis meliputi warna permukaan koloni, warna sebalik koloni, permukaan koloni, diameter koloni, radial furrow, growing zone, dan exudate drops, sedangkan pengamatan mikroskopis meliputi: Spora (bentuk, panjang dan lebar sel konidia, permukaan), konidiofor (permukaan, panjang dan lebar konidiofor, pewarnaan sel), vesikula, metula, fialid, dan struktur tambahan (khlamidospora, septat pada hifa). Pengamatan mikroskopis menggunakan pewarna lactophenol blue dan pengamatan dilakukan menggunakan mikroskop cahaya dengan perbesaran 1000x.

Hasil pengamatan makroskopis dan mikroskopis selanjutnya diidentifikasi menggunakan metode profile matching yaitu membandingkan hasil pengamatan karakter fenotipe mikroskopis dan makroskopis kapang dengan beberapa buku rujukukan (buku identifikasi kapang) antara lain : Pengenalan Kapang Tropik Umum (Indrawati et al, 1999) ; Identification Of Pathogenic Fungi (Colin et al, 2013) ; Descriptions Of Medical Fungi (David et al, 2007) dan berdasarkan hasil penelitian terkait.

\section{Teknik Analisis Data}

Data hasil karakterisasi dilakukan identifikasi sampai pada tingkatan genus dan dibahas secara deskriptif sesuai dengan ciri - ciri mendasar berdasarkan buku identifikasi rujukkan dan dilakukan analisis deskriptif mengenai peranan kapang yang telah diisolasi dalam proses kerusakan batuan Candi Borobudur.

\section{HASIL DAN PEMBAHASAN}

\section{Isolasi dan Karakterisasi Kapang Pada Batuan Candi Borobudur}

Pengambilan sampel kapang pada batuan Candi Borobudur dilakukan menggunakan teknik purposive sampling. Menurut Sugiyono (2013) Purposive sampling merupakan teknik penentuan sampel dengan pertimbangan tertentu. Adapun kriteria pengambilan sampel pada penelitian ini adalah batuan Candi Borobudur yang mengalami kerusakan lubang-lubang kecil, perubahan warna batuan, batuan candi yang menampakkan spora atau miselium kapang, serta menampakkan kerak berwarna putih atau putih kekuningan. Gambar 1. merupakan contoh perbandingan sampel batuan yang ditumbuhi kapang dan tidak ditumbuhi kapang. 


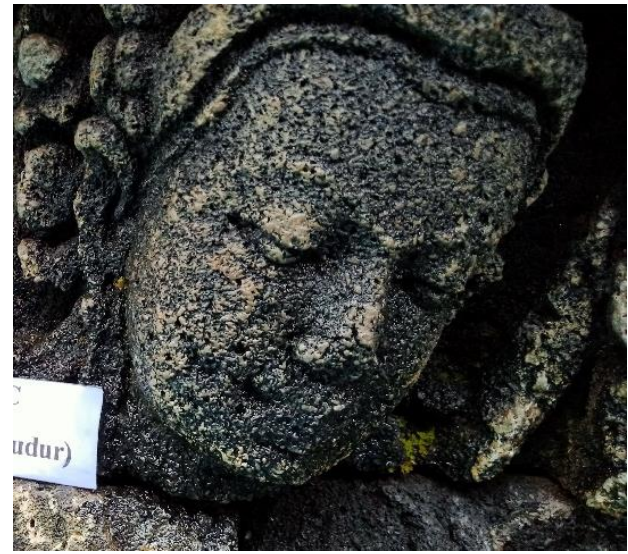

a

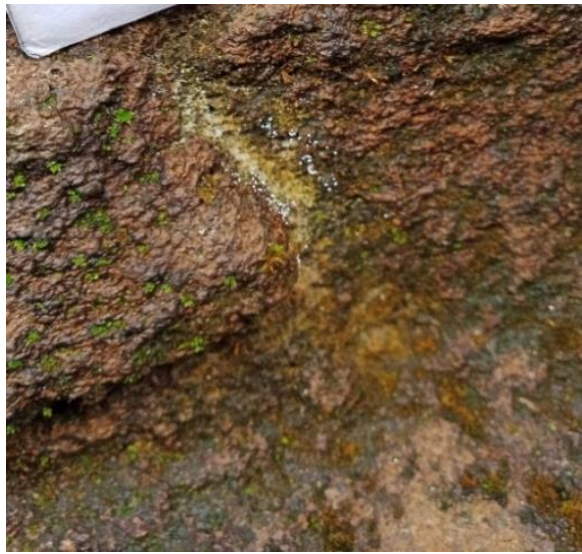

$\mathrm{b}$

Gambar 1. (a) Contoh batuan yang tidak ditumbuhi kapang (b) Contoh batuan yang ditumbuhi kapang

(Sumber: Penulis, 2021)

Metode pengambilan sampel kapang pada batuan Candi Borobudur dilakukan dengan metode $s w a b$ dan kerik. Metode swab dilakukan dengan mengambil apusan pada batu yang menampakkan bercak putih dengan swab steril. Olesan atau apusan dilakukan pada luas permukaan $2 \times 2 \mathrm{~cm}^{2}$ selama kurang lebih 30 detik (Didem et al, 2018 dalam Riadi, 2020). Pengusapan dilakukan secara horizontal kemudian vertikal untuk menutupi area (Abott dan Sean, 2004 dalam Riadi, 2020). Swab steril yang telah dipenuhi apusan dimasukkan ke dalam tabung swab steril kemudian diisolasi pada media secara aseptis di laboratorium biologi Balai Konservasi Borobudur.

Metode kerik dilakukan dengan mengambil bagian batu yang lembab, menampakkan bercak puth maupun kekuningan, atau pada batu yang lapuk dengan menggunakan skapel. Kerikan dilakukan sebanyak 2 -3 kali. Sampel kerikan ditampung dalam plastik ziplock steril kemudian diisolasi pada media secara aseptis di laboratorium dalam rentang waktu 24 jam (Nabiilah \& Dina, 2016). Setelah dilakukan pengambilan sampel kapang dengan metode swab maupun kerik, masing-masing sampel kapang pada tiap titik sampling diisolasikan pada media CDA secara aseptis di laboratorium biologi Balai Konservasi Borobudur. Berdasarkan hasil isolasi kapang pada lantai II sisi selatan, utara dan timur Candi Borobudur ditemukan kapang kontaminan yang bervariasi pada tiap titik sampling. Dari hasil isolasi terdapat 80 isolat dan setelah diidentifikasi terdapat 5 genus yang yaitu Penicillium, Paecilomyces, Mucor, Cladosporium dan Aspergillus. 
a. Penicillium

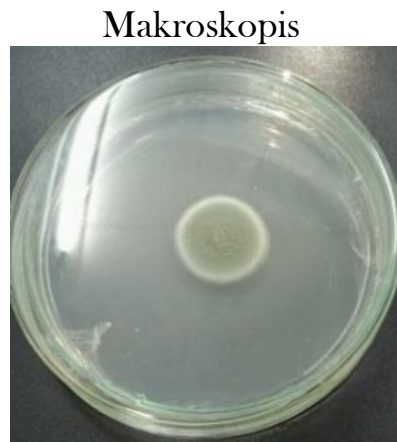

a

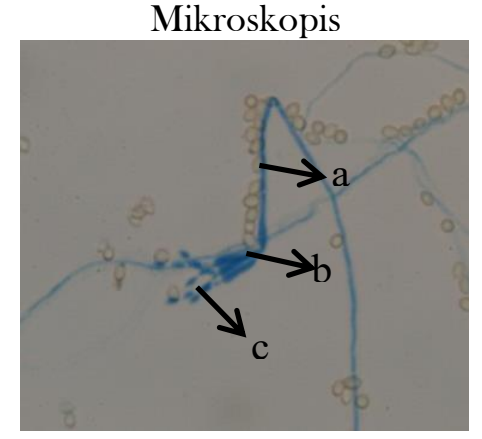

b

Gambar 2. (a) pengamatan makroskopis Isolat kapang (b) pengamatan mikroskopis dengan perbesaran 1000x dengan pewarna lactophenol blue a. Konidiofor, b. Fialid, c. Konidia

(Sumber : Penulis, 2021)

Berdasarkan hasil pengamatan makroskopis, Penicillium memiliki diameter berkisar antara 21 - $41 \mathrm{~mm}$ setelah inkubasi selama 7 hari pada suhu ruang. Penicillium memiliki hifa berseptat, miselium bercabang dan umumnya berwarna. Konidiofor berseptat dan muncul di atas permukaan dengan kepala berbentuk seperti sapu dengan fialid atau sterigmata

Koloni Penicillium umumnya tumbuh cepat, berwarna hijau atau putih, sebagian besar terdiri dari konidiofor yang padat. Secara mikroskopis, rantai konidia bersel tunggal diproduksi dalam suksesi basipetal dari sel konidiogen khusus yang disebut dengan fialid. Fialid pada genus Penicillium dapat diproduksi sendiri-sendiri dalam kelompok atau dari metula bercabang, berbentuk seperti sapu (penisilus). Penicillus memiliki dua cabang dan metulae (cabang kedua dari belakang yang memiliki lingkaran fialid). Pada sel di antara metula dan tonjolan konidiofor disebut sebagai cabang. Penicillium memiliki konidiofor hialin, berdinding halus atau kasar. Fialid umumnya berbentuk labu, terdiri dari bagian basal silinder dan leher yang berbeda, atau lanset (kurang lebih dengan bagian basal sempit meruncing ke agak runcing puncak). Konidia berada dalam rantai kering panjang, divergen atau dalam kolom, berbentuk bulat, ellipsoidal, silindris atau fusiform, berwarna hialin atau kehijauan dan berdinding halus atau berdinding kasar. Beberapa spesies Penicillium merupakan kontaminan umum pada berbagai substrat, sebagai produsen mikotoksin potensial, dan sebagai parasit pada tanaman (David et al, 2007). 


\section{b. Paecilomyces}

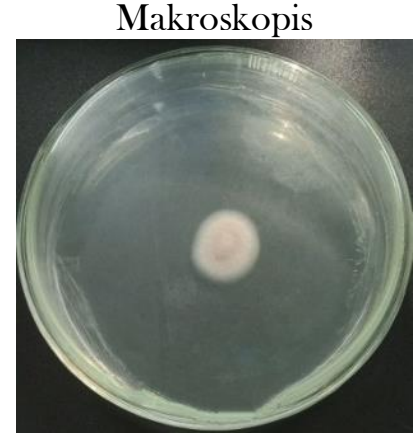

a

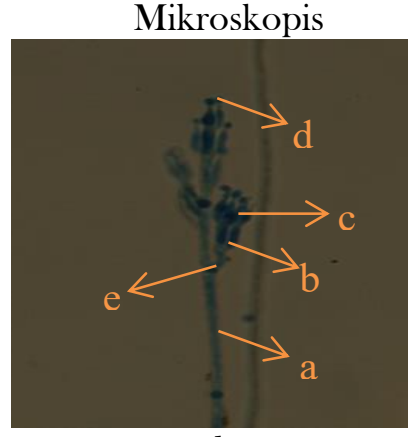

b.

Gambar 3. a) pengamatan makroskopis Isolat kapang Paecilomyces (b) pengamatan mikroskopis perbesaran 1000x dengan pewarna I lactophenol blue a. konidiofor b. metula c. fialid d. konidia e. percabangan

(Sumber: Penulis, 2021)

Berdasarkan hasil pengamatan makroskopis, Paecilomyces memiliki diameter berkisar antara 13 - $29 \mathrm{~mm}$ setelah inkubasi selama 7 hari pada suhu ruang. Hasil pengamatan makroskopis menunjukkan bahwa genus Paecilomyces dan Penicillium memiliki struktur makroskopis yang hampir sama yaitu kepala konidia berbentuk seperti sapu dengan fialid atau sterigmata. Konidiofor berbentuk subglobose atau elips dengan ukuran $(1-4,5 \mu \mathrm{m}) \mathrm{x}(1-1,5 \mu \mathrm{m})$ dan berdinding halus. Konidiofor berseptat, berukiran $(100$ $-240 \mu \mathrm{m}) \times(2-3 \mu \mathrm{m})$. Perbedaan genus Paecilomyces dengan genus Penicillium yaitu genus Paecilomyces memiliki fialid panjang dan ramping yang berbeda dengan genus Penicillium serta koloni Paecilomyces biasanya tidak pernah bewarna hijau (David et al, 2007). Menurut Indrawati Gandjar et al (1999) Paecilomyces umumnya berwarna merah lembayung redup dengan warna sebalik koloni tidak berwarna atau sedikit merah lembayung. genus Paecilomyces memiliki konidiofor yang lurus dengan panjang $400-600 \mu \mathrm{m}$ dan lebar 3 - 4 $\mu \mathrm{m}$, biasanya muncul soliter dari miselium yang tumbuh horizontal, berwarna kuning hingga ungu, berdinding kasar, membawa klaster metula dan fialid yang lebat. Konidia berbentuk elips hingga fusiform berdinding halus, namun terkadang sedikit kasar. Genus ini umumnya merupakan penghuni tanah dan kosmopolit, serta banyak ditemukan pada daerah tropis.

a. Mucor

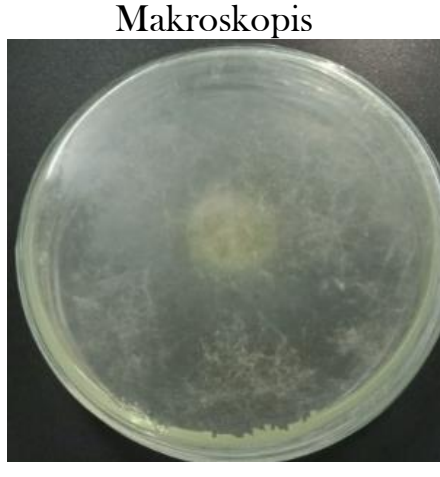

a

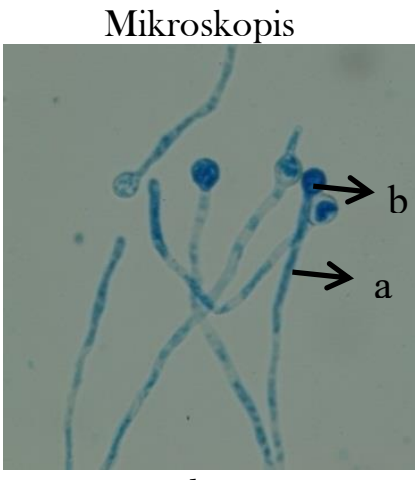

b

Gambar 4. pengamatan makroskopis Isolat kapang Mucor (b) pengamatan mikroskopis perbesaran 1000x dengan pewarna lactophenol blue a. sporangiofor b. sporangium

(Sumber : Penulis, 2021) 
Berdasarkan hasil pengamatan makroskopis, Mucor memiliki diameter berkisar 21 mm setelah inkubasi selama 7 hari pada suhu ruang. Tekstur permukaan kapang seperti kapas dan berwarna putih kekuningan. Genus Mucor memiliki bentuk sporangium globose, dinding sel halus berukuran $(4-6,5 \mu \mathrm{m})$ x $4-5 \mu \mathrm{m}$. Sporangiofor berukuran $(100-150 \mu \mathrm{m})$ $\mathrm{x}(1,5-2,5 \mu \mathrm{m})$ berdinding halus, dengan bentuk sederhana dan tidak terdapat stolon. Hal tersebut sesuai dengan David et al (2007) Koloni dapat tumbuh dengan cepat, koloni seperti kapas hingga halus, berwarna putih menjadi kuning, menjadi abu-abu tua, dengan perkembangan sporangia. Sporangiofor tegak, sederhana atau bercabang dengan diameter 60-300 $\mu \mathrm{m}$, sporangia berbentuk bulat, multispora, tanpa apophyses. Terdapat kerah yang mencolok (sisa-sisa dinding sporangial) yang umumnya terlihat di dasar kolumela setelah sporangiospore menyebar. Sporangiospora berwarna hialin, abu-abu atau kecoklatan, bulat menjadi ellipsoidal, dan berdinding halus. Klamidospora dan zigospora juga dapat ditemukan.

\section{b. Cladosporium}

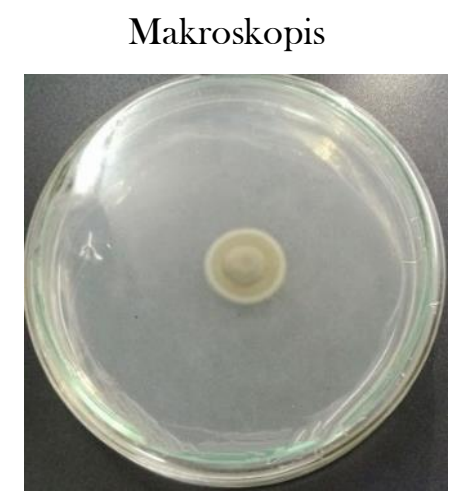

a

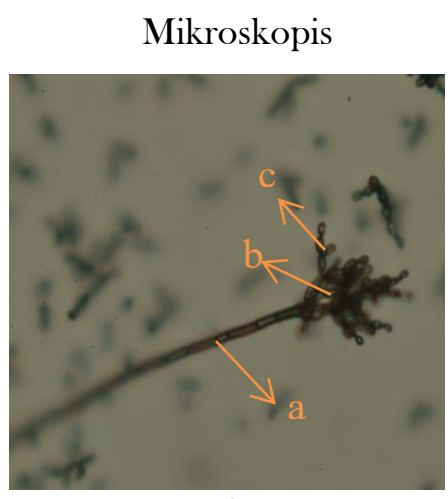

b

Gambar 5. pengamatan makroskopis Isolat kapang Cladosporium (b) pengamatan mikroskopis perbesaran 1000x dengan pewarna lactophenol blue a.konidiofor b.ramokonidia c. konidia (Sumber : Penulis, 2021)

Berdasarkan hasil pengamatan makroskopis, Cladosporium memiliki diameter berkisar antara 16 - $26 \mathrm{~mm}$ setelah inkubasi selama 7 hari pada suhu ruang. Genus Cladosporium memiliki tekstur bergranul berwarna hijau (olive green).

Hasil pengamatan mikroskopis menunjukkan bahwa genus Cladosporium memiliki konidia berbentuk elips, berdinding halus, terdapat ramokonidia pada basis dari rantai konidia. Konidiofor berseptat dan berdinding halus berukuran $(20-135 \mu \mathrm{m}) \times(2-2,5 \mu \mathrm{m})$. Hasil pengamatan tersebut sesuai dengan Indrawati et al, (1999) Penampakan koloni awal genus Cladosporium seperti beludru, kemudian berubah seperti tepung halus karena adanya pembentukan konidia yang lebat. Koloni berwarna hijau tua kecoklatan atau hijau keabuabuan dengan warna sebalik koloni hijau kehitaman. Konidiofor terbentuk lateral atau terminal pada hifa, dengan panjang konidiofor dapat mencapai $350 \mu \mathrm{m}$ dan lebar $2-6 \mu \mathrm{m}$. Konidia berbentuk rantai, berwarna pucat coklat kehijauan dengan dinding halus atau sedikit kasar. Konidia terdapat pada rantai yang bercabang akropetal, umumnya bersel satu, berbentuk silindris. Terdapat ramokonidia yang berada basis dari rantai, bersepta 1 hingga 2 dengan bentuk silindris. 
c. Aspergillus

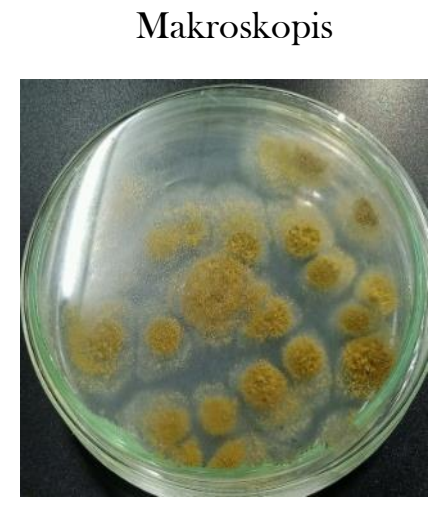

a

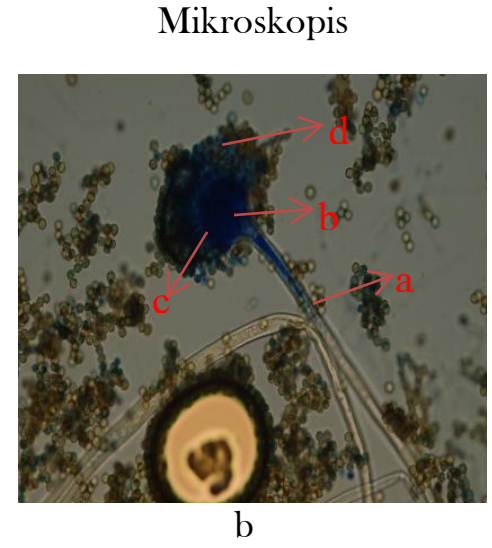

Gambar 5. (a) pengamatan makroskopis Isolat kapang Aspergillus (b) pengamatan mikroskopis perbesaran 1000x dengan pewarna lactophenol blue a.konidiofor b.vesikula c. fialid d. konidia (Sumber : Penulis, 2021)

Berdasarkan hasil pengamatan makroskopis, Aspergillus memiliki diameter berkisar antara 28 - $34 \mathrm{~mm}$ setelah inkubasi selama 7 hari pada suhu ruang. Pada pengamatan mikroskopis, genus Aspergillus memiliki konidia benbentuk globose, berukuran (4-6 $-6 \mathrm{~m}) \mathrm{x}$ (4 -6 $\mu \mathrm{m})$ dan berdinding halus. Terdapat vesikula berbentuk semibulat dan pada bagian atasnya terbentuk fialid. Konidiofor berseptat ataupun tidak berseptat, berukuran (80 - 200 $\mu \mathrm{m}) \mathrm{x}(4,3-5,8 \mu \mathrm{m})$ dan berdinding halus. Hal tersebut sesuai menurut Waluyo (2004) ciri ciri spesifik genus Aspergillus antara lain : Memiliki hifa berseptat dan miselium yang bercabang. Hifa yang muncul pada permukaan umumnya adalah hifa fertil. Koloni hidup berkelompok. Konidiofor yang berseptat atau tidak berseptat muncul dari sel miselium yang membengkak dan berdinding tebal. Konidiofor dapa membengkak menjadi vesikula pada bagian ujungnya, dan membawa sterigmata tempat tumbuhnya konidia. Sterigmata atau fialid umumnya sederhana, berwana atau tidak. Konidia membentuk rantai yang berwarna hijau, coklat atau hitam.

Aspergillus merupakan genus kapang yang bersifat saprofit dan parasit yang umumnya dapat hidup pada daerah yang lembab maupun di daerah tropis dan subtropis tergantung pada kondisi lingkungan. Genus ini membentuk filamen-filamen panjang bercabang, dan dalam media biakan membentuk miselia dan konidiospora.. Aspergillus menghasilkan konidium yang disangga konodiofor. Ujung konidiofornya berbentuk seperti bola dengan sejumlah cabang yang masing- masing menyangga ranting konidium. Aspergillus mempunyai konidium di bagian ujungnya dan mempunyai hifa bersekat serta bersepta (Crystovel, 2016).

\section{Tingkat Keanekaragaman dan Biodiversitas Kapang pada Batuan Candi Borobudur}

Terdapat banyak faktor yang dapat mempengaruhi dominasi persebaran genus kapang, seperti faktor lingkungan, kondisi batuan, dan ketersediaan unsur hara pada subtrat batuan tersebut. Kondisi struktur batuan baik secara fisik maupun kimiawi tentu memberikan pengaruh terhadap pertumbuhan masing-masing genus kapang. Meskipun penyusun batuan Candi Borobudur merupakan batuan andesit, namun tingkat porositas antara batu satu dengan lainnya tentu berbeda. Semakin tinggi nilai porositasnya dapat meningkatkan kelembapan pada batuan, hal tersebut tentu dapat mempengaruhi pertumbuhan kapang semakin meluas. Selain itu kemampuan kapang dalam melakukan penetrasi hifa pada subtrat batuan juga dapat mendukung pertumbuhannya. Berikut tabel 1 
dan Gambar 2. merupakan persebaran dan persentase kapang pada batuan Candi Borobudur.

Tabel 1. Persebaran dan persentase genus kapang

Genus Jumlah Titik pengambilan sampel persentase $\begin{array}{lllllllllllllll}\text { isolat } & A & B & C & D & E & F & G & H & I\end{array}$

\begin{tabular}{|c|c|c|c|c|c|c|c|c|c|}
\hline Penicillium & 9 & $\sqrt{ }$ & & & & $\sqrt{ }$ & & $\sqrt{ }$ & $11,25 \%$ \\
\hline Paecilomyces & 54 & $\sqrt{ }$ & $\sqrt{ }$ & & $\sqrt{ }$ & $\sqrt{ }$ & $\sqrt{ }$ & $\sqrt{ }$ & $67,5 \%$ \\
\hline Mucor & 1 & & & & & & & & $1,25 \%$ \\
\hline Cladosporium & 9 & & $\sqrt{ }$ & $\sqrt{ }$ & $\sqrt{ }$ & & $\sqrt{ }$ & & $11,25 \%$ \\
\hline Aspergillus & 7 & & & & & $\sqrt{ }$ & & & 8,75 \\
\hline
\end{tabular}

Jumlah Isolat $\quad 80$

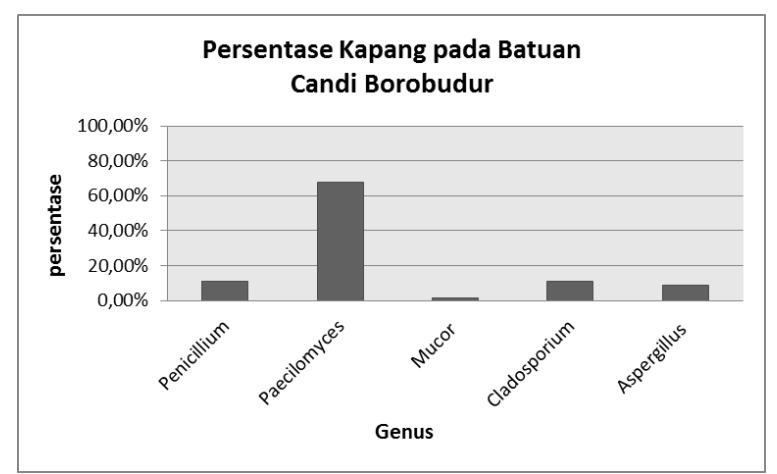

Gambar 7. Diagram persentase kapang pada batuan Candi Borobudur

(Sumber: Penulis, 2021)

Pada grafik di atas menunjukkan bahwa genus Paecilomyces merupakan dominasi tertinggi yaitu sebesar 67,5\%. Selain itu genus Paecilomyces juga memiliki titik persebaran tertinggi diantara genus lainnya yaitu ditemukan pada 6 titik dari 9 titik lokasi pengambilan sampel. Genus Paecilomyces merupakan salah satu genus yang sering ditemui pada monumen monumen bersejarah di dunia, salah satunya pada penelitian Sanjay dan Kavita (2011) mengenai biodeteriorasi dan preservasi Candi Sita di India. Genus Paecilomyces umumnya berwarna merah lembayung redup dengan warna sebalik koloni tidak berwarna atau sedikit merah lembayung. Genus ini umumnya merupakan penghuni tanah dan kosmopolit, serta banyak ditemukan pada daerah tropis (Indrawati et al, 1999). Paecilomyces merupakan jenis kapang kosmopolit yaitu jenis kapang yang memiliki daerah penyebarannya sangat luas, sebab kapang ini dapat diisolasi dari tanah, dan sisa tanaman yang telah membusuk (Efa dkk, 2014).

Genus Cladosporium dan Penicillium merupakan genus dengan persentase 11,25\% dan tingkat persebaran kedua. Genus Cladosporium tersebar pada 4 titik sampling. 
Cladosporium juga merupakan genus yang sering dijumpai sebagai salah satu biodeteriogen pada batuan monumen bersejarah seperti pada batu kuburan cyrus agung dan monumen batu Dharmarajika, Taxila. Menurut penelitian Tikam Chand \& Swaranjit (2012) jenis kerusakan pada batuan yang disebabkan oleh Cladosporium diantaranya adalah pitting atau korosi sumuran berupa lubang-lubang kecil, sekresi asam dan pelapukan. Persentase ketiga adalah genus Aspergillus yaitu 8,75\%, kemudian genus dengan persentase terendah adalah Mucor yaitu sebesar 1.25\%. Menurut hasil penelitian Farooq et al (2015) menunjukkan bahwa genus Aspergillus, Mucor dan Penicillium merupakan genus yang menghasilkan asam organik yang tinggi dan sering dijumpai sebagai agen biodeteriogen pada batuan. Pada penelitian tersebut ditemukan bahwa genus Penicillium dikaitkan dengan pembentukan biofilm hitam di permukaan monumen tersebut. selain itu ditemukan pula genus Aspergillus sebagai penyebab adanya noda hitam pada batu monumen.

\section{Biodeteriorasi dan Perawatan Batuan Candi Borobudur}

Menurut Leliek et al (2014) secara umum batuan penyusun Candi Borobudur adalah batuan andesit. Namun secara spesifik batuan tersebut memiliki karakteristik yang berbeda- beda. Hal tersebut menyebabkan setiap batuan dapat mengalami kerusakan yang berbeda-beda.

Karakteristik fisik maupun kimia batuan juga berpengaruh pada biodeteriorasi batuan Candi. Analisis sifat fisik dan kimia batuan Candi Borobudur berdasarkan hasil penelitian Leliek et al (2014) dapat dilihat pada tabel 2. dan tabel 3. Pada penelitian tersebut sampel andesit diambil dari batu candi yang ada di tempat penyimpanan batu (kondisinya relatif sama dengan di candi/di tempat terbuka) yang terletak di sebelah barat Candi Borobudur, sehingga tidak merusak batu yang ada di candi.

Tabel 2. Sifat fisik batu penyusun Candi Borobudur

\begin{tabular}{llllll} 
Parameter & a & b & c & d & e \\
\hline Densitas (gr/cm $)$ & 2,14 & 2,12 & 2,21 & 2,18 & 2,23 \\
Berat jenis & 2,67 & 2,63 & 2,7 & 2,68 & 2,71 \\
\hline Porositas (\%) & 19,45 & 20,35 & 18,78 & 19,24 & 17,96 \\
\hline Daya serap air (\%) & 10,68 & 10,94 & 9,78 & 10,23 & 9,25 \\
Kekerasan(mohs) & $4-6$ & $4-6$ & $4-6$ & $4-6$ & $4-6$ \\
\hline Temperatur batu ( $\left.{ }^{\circ} \mathbf{C}\right)$ & 45,2 & 44,7 & 47,1 & 45,9 & 48,6 \\
& Sumber: Leliek et al, 2014 & &
\end{tabular}


Tabel 3. Komposisi kimia batu penyusun Candi Borobudur

\begin{tabular}{|c|c|c|c|c|c|}
\hline Parameter & $\mathbf{a}$ & b & c & d & e \\
\hline $\mathrm{Al}_{2} \mathrm{O}_{3}$ & 16,93 & 17,19 & 14,35 & 15,47 & 13,00 \\
\hline $\mathrm{CaO}$ & 2,68 & 2,60 & 3,89 & 3,50 & 1,96 \\
\hline $\mathrm{FeO}$ & 4,78 & 4,62 & 6,03 & 5,37 & 6,78 \\
\hline $\mathrm{Fe}_{2} \mathrm{O}_{3}$ & 5,31 & 5,14 & 6,71 & 5,97 & 7,53 \\
\hline $\mathrm{MgO}$ & 1,57 & 0,62 & 1,55 & 0,62 & 1,29 \\
\hline $\mathrm{Na}_{2} \mathrm{O}$ & 3,81 & 3,50 & 4,13 & 4,02 & 3,29 \\
\hline $\mathrm{K}_{2} \mathrm{O}$ & 2,83 & 2,35 & 2,65 & 2,88 & 2,73 \\
\hline $\mathrm{SiO}_{2}$ & 59,69 & 59,97 & 58,15 & 58,20 & 56,12 \\
\hline
\end{tabular}

Struktur batuan dengan rapat massa yang relatif lebih kecil dapat lebih mudah ditumbuhi oleh organisme yang menyebabkan kerusakan batuan candi. batu yang memiliki rapat massa lebih kecil memiliki pori-pori yang lebih besar, sehingga akan dapat menyerap dan menyimpan air lebih besar pula yang mengakibatkan kelembaban batu akan lebih tinggi. Nilai porositas yang lebih tinggi dapat lebih mudah untuk ditumbuh biodeteriogen. densitas dan porositas batu yang memungkinkan terjadinya pelapukan lebih cepat, sehingga menyebabkan kekerasan batu menjadi rendah. Pelapukan menjadi semakin intensif karena adanya pertumbuhan organisme maupun mikroorganisme seperti kapang.

Sebagai organisme heterotrof, kapang tidak dapat mengkonsumsi substrat karbonat anorganik untuk mendukung pertumbuhannya, tetapi dapat tumbuh pada produk limbah atau sel mati dari organisme lain dan sisa bahan nitrogen organik dari kotoran burung, tumbuhan yang sudah mati dan membusuk dan aerosol yang ada di atas permukaan batu, celah, retakan, lingkungan subaerial dan subsoil pada batu. Kemampuan kapang untuk tumbuh sebagai oligotrof dan mengambil bahan nutrisi dari atmosfer dan air hujan memungkinkan pertumbuhan kapang di lingkungan batuan.

Menurut Parisa \& Nasim (2014) kapang yang ditemukan di batu dapat tumbuh pada permukaan batuan yang disebut epilith atau dapat menembus pori-pori batuan yang disebut endolith. Kapang juga dapat menyebabkan perubahan warna batuan dan juga mengekskresikan berbagai jenis asam organik seperti asam oksalat, asam glukonat dan asam laktat yang mengkelat magnesium, mangan, besi dan ion kalsium dari permukaan batu dan biodeteriorasi batu. 
Berdasarkan hasil identifikasi terdapat 5 genus kapang yang ditemukan pada batuan Candi Borobudur yaitu Penicillium, Paecilomyces, Mucor, Aspergillus, dan Cladosporium. Menurut hasil penelitian Farooq et al (2015) menunjukkan bahwa kapang penghasil asam tertinggi adalah dari genus Aspergillus, Fusarium, Mucor Penicillium, Trichoderma dan Rhizopus sedangkan Jamur penghasil asam terendah adalah Alternaria alternata, Cladosporium, dan Curvularia lunata. Asam yang paling umum dihasilkan yaitu asam sitrat, asam oksalat, asam glukonat, asam suksinat, asam fumarat dan asam asetat.

Berdasarkan hal tersebut pada penelitian ditemukan bahwa genus Penicillium, Aspergillus dan Paecilomyces terdapat pada satu titik yang sama. Ketiga kapang tersebut terdapat pada titik $\mathrm{F}$ dengan pengambilan sampel menggunakan metode kerik, namun pada permukaan batuan belum menunjukkan tampilan warna tertentu (khusus) yang dapat menggambarkan adanya keanekaragamn kapang pada batuan tersebut. Interaksi dan pertumbuhan kapang-kapang pada batuan tersebut memungkinkan dapat meningkatkan terjadinya biodeteriorasi. Seperti pada penelitian yang telah dilakukan pada monumen batu kapur di Katedral Spanyol ditemukan bahwa genus Penicillium dikaitkan dengan pembentukan biofilm hitam di permukaan monumen tersebut. selain itu ditemukan pula genus Aspergillus sebagai penyebab adanya noda hitam pada batu monumen. Pertumbuhan kapang pada permukaan batu dapat mengeksresikan asam anorganik dan organik sebagai hasil dari metabolisme. Asam organik yang dihasilkan secara metabolik ini (seperti asam oksalat dan asam sitrat) memiliki sifat pengkelat yang melemahkan ikatan metaloksigen, meningkatkan kelarutan beberapa logam dan membentuk kompleks dengan kation mineral yang ada pada matriks permukaan.

Beberapa genus kapang telah banyak diisolasi dari monumen batu yang terletak di berbagai negara diantaranya Spesies dari Alternaria, Aspergillus, Acremonium, Arthobotrys, Auerobasidium, Cladosporium, Curvularia, Drechslera, Fusarium, Helminthosporium, Mucor, Phoma, Penicillium, Rhizopus, Trichothecium dan Trichoderma telah dilaporkan sebagai kapang yang umum terlibat dalam pembusukan biologis monumen batu. Pada penelitian Sanjay dan Kavita (2011) juga ditemukan kapang serupa pada biodeteriorasi batuan candi. Kapang tersebut diantaranya genus Aspergillus, Cladosporium, Curvularia, Fusarium, Mucor, Paecilomyces, Penicillium dan Trichoderma.

Menurut penelitian Parisa \& Nasim (2014) Kapang menghasilkan beberapa asam anorganik dan organik selama aktivitas metabolisme di monumen. Asam tersebut menyebabkan pelarutan mineral dan mengubah konfigurasi struktural material batu. Asam organik seperti asam oksalat, laktat dan glukonat berfungsi sebagai agen pengkelat dan dapat mendemineralisasi berbagai substrat batu termasuk kalsium, silikon, besi, magnesium, dan mangan. Enzim yang diproduksi selama aktivitas metabolisme jamur terlibat dalam transformasi molekul kompleks dan mengikat monumen batu menjadi molekul larut sederhana. Metabolit kapang dapat menyebabkan pelarutan kation dan menghasilkan patina 
dengan komposisi mineralogi yang berbeda. Perubahan warna monumen akibat pembentukan patina lebih banyak merusak monumen batu berwarna terang.

Interaksi antara hifa jamur dan substrat batu juga menyebabkan terbentuknya biofilm yang ditandai dengan perubahan warna pada batuan sehingga menyebabkan biodeteriorasi pada batuan. Cyanobacter merupakan organisme pioner dalam pembentukan biofilm. Cyanobacter dapat menempel pada permukaan substrat kemudian bersimbiosis dengan organisme lain seperti alga maupun jenis jamur atau kapang untuk membentuk biofilm. Pembentukan biofilm tersebut tidak hanya terdiri dari satu organisme, tetapi terdiri dari beberapa organisme yang bekerja secara sinergis untuk merusak batuan. Proses tersebut dapat menyebabkan terjadinya perubahan warna.

Pembentukan biofilm pada permukaan batuan berperan dalam proses pembentukan biopatina dalam kurun waktu yang sangat lama. Terbentuknya biopatina dapat menyebabkan perubahan warna, perubahan komposisi dan struktur pada permukaan batuan. Menurut Harbowo (2011) Biofilm tersebut dapat menyebabkan mikroorganisme di beberapa bagian batu mengalami kekurangan oksigen sehingga terjadi reaksi anaerob yang mampu mengubah bilangan oksidasi unsur dan penggaraman. Selain itu biopatina dapat terjadi akibat pembentukan pigmen oleh mikroorganisme seperti kapang di permukaan batuan yang dapat menyebabkan perubahan penampakan batuan. Dengan adanya mikroorganisme tersebut akan dimungkinkan pula terjadi perubahan komposisi pada permukaan batuan. Pembentukan biopatina dapat memicu terjadinya proses yang mampu membentuk cekungan dan penumpukan kerak pada batuan sehingga merubah penampakan stuktur batuan.

Berdasarkan hasil penelitian, kelima genus yang ditemukan pada batuan Candi Borobudur yaitu Penicillium, Paecilomyces, Mucor, Aspergillus, dan Cladosporium berpotensi dalam proses biodeterioraasi batuan Candi Borobudur. Hal tersebut dapat terjadi karena adanya penetrasi hifa kapang dalam batuan candi dan asam organik yang kemungkinan dihasilkan dalam aktivitas pertumbuhan kapang tersebut. Selain itu kapang juga berperan dalam pembentukan biofilm pada permukaan batuan Candi Borobudur. Jenis kerusakan yang dapat ditimbulkan akibat adanya pertumbuhan kapang pada batuan Candi Borobudur diantaranya yaitu perubahan warna, pembentukan biofilm, penggaraman, dan terbentuknya lubang-lubang kecil pada permukaan batuan.

Faktor lingkungan merupakan faktor penting yang mendukung pertumbuhan kapang. Kondisi lingkungan seperti kelembaban relatif, suhu, angin, cahaya dan curah hujan berperan penting dalam kolonisasi dan pembentukan mikroba pada permukaan batu candi. Permasalahan tersebut sering terjadi di daerah tropis di mana suhu tinggi, kelembaban relatif tinggi dan curah hujan tahunan yang tinggi dapat mendukung pertumbuhan kelompok mikroorganisme yang beragam (Tikam Chand \& Swaranjit, 2012 : 1). Menurut barnet \& Hunter (1998) Suhu dan kelembaban adalah faktor umum yang mempengaruhi 
pertumbuhan organisme. Setiap jenis kapang memiliki pertumbuhan optimum yang berbeda-beda karena berbagai faktor, namun secara umum kapang dapat tumbuh pada suhu mesofilik yaitu $20{ }^{\circ} \mathrm{C}-30^{\circ} \mathrm{C}$. Berdasarkan data kondisi lingkungan mikroklimat Candi Borobudur bulan Desember 2020 - Februari 2021 menunjukkan bahwa suhu lingkungan Candi Borobudur berkisar antara $23^{\circ} \mathrm{C}-29^{\circ} \mathrm{C}$. Rentang suhu tersebut dapat mendukung pertumbuhan kapang secara umum dan sesuai dengan barnet \& Hunter (1998) bahwa pertumbuhan kapang berkisar pada suhu $23^{\circ} \mathrm{C}-29^{\circ} \mathrm{C}$.

Pertumbuhan hifa kapang pada batu candi, dapat mengganggu kestabilan tekstur batu sehingga mengakibatkan kerusakan mekanis pada batu tersebut. Rata-rata kerusakan mekanis lainnya diakibatkan oleh kontraksi dan ekspansi bergantian dari thallus dalam kondisi kelembaban lingkungan yang berfluktuasi. Beberapa kapang endolitik secara biokimia menyebabkan terjadinya "pitting", pada permukaan batu sehingga menampakkan banyak lubang-lubang kecil (Tikam Chand \& Swaranjit, 2012).

Menurut Suhartono dkk (2018) Berdasarkan hasil studi Balai Konservasi Peninggalan Borobudur, air yang terdapat pada struktur Candi Borobudur merupakan penyebab terbesar dari kerusakan dan pelapukan pada batu candi khususnya pada bagian permukaannya. Kerusakan tersebut terjadi karena adanya penetrasi air ke dalam struktur candi yang disebabkan oleh adanya kebocoran pada dinding yang mempunyai pahatan relief cerita. Air tersebut masuk melalui nat-nat atau sela-sela batu pada struktur candi di atasnya, sehingga mirkoorganisme seperti kapang dapat lebih mudah tubuh dan lambat laun menyebabkan kerusakan maupun pelapukan pada batuan candi.

Kondisi arsitektural Candi Borobudur yang terbuka dan tanpa atap menyebabkan permukaan batu candi berinteraksi langsung lingkungan di sekitarnya. Kondisi tersebut tidak akan terlepas dari berbagai permasalahan yang dapat menyebabkan kerusakan batuan candi, namun hal tersebut dapat diminimalisir dengan berbagai macam upaya. Upaya yang dapat dilakukan untuk mengurangi pertumbuhan kapang sebagai agen biodeteriogen pada batuan Candi dapat dilakukan pembersihan batuan Candi Borobudur secara rutin. Pembersihan dilakukan terutama pada sela sela dinding candi yang lembab dan kurang terkena cahaya matahari. Menurut Yanuardi (2009) pembersihan batuan candi harus memiliki beberapa prinsip yaitu: dilakukan dalam keadaan kering (jika memungkinkan), apabila dilakukan pembersihan secara basah, harus menggunakan air bersih (tidak ada garam-garam terlarut), salinitas air $(\mathrm{pH})$ harus netral, air pembersihan harus dilokalisasi, dan menggunakan peralatan yang tidak dapat merusak permukaan benda. Selain itu, upaya pembersihan dilakukan dengan prinsip minimum intervention, yang artinya upaya pembersihan tersebut dilakukan untuk meminimalkan efek dari mikroba penggaggu tersebut. Apabila dengan pembersihan tersebut dianggap telah aman dari gangguan dan penyebabnya, upaya pembersihan harus dihentikan, tidak boleh berlebihan hingga menyebabkan over-cleaning. 
Selain itu, dapat dilakukan penelitian lebih lanjut mengenai cara meminimalisir dan menghambat pertumbuhan kapang pada batuan Candi Borobudur menggunakan bahan alami yang ramah lingkungan dan tidak membahayakan kesehatan manusia.

\section{KESIMPULAN}

Berdasarkan hasil penelitian yang telah dilakukan, dapat disimpulkan bahwa:

1. Jumlah isolat kapang yang ditemukan pada batuan Candi Borobudur adalah 80 isolat. Kapang yang teridentifikasi sebagai biodeteriogen pada batuan Candi Boobudur adalah genus Paecilomyces dengan persentase tertinggi yaitu 67,5\%, genus Cladosporium dengan persentase 11,25\%, genus Penicillium dengan persentase 11,25\%, genus Aspergillus dengan persentase 8,75 dan genus Mucor dengan persentase 1,25\%.

2. Berdasarkan hasil pengamatan pada penelitian ini, batuan Candi Borobudur telah mengalami biodeteriorasi. Jenis kerusakan yang kemungkinan dapat ditimbulkan akibat adanya kapang kontaminan pada batuan Candi Borobudur adalah perubahan warna pada permukaan batuan candi yang menampakkan kerak berwarna putih maupun putih kekuningan, dan pembentukan biofilm. hal tersebut dapat mengurangi nilai estetika dari Candi Borobudur. Selain itu, apabila pertumbuhan kapang semakin meluas dapat menimbulkan kerusakan fisik seperti munculnya lubang-lubang kecil pada batuan

\section{SARAN/REKOMENDASI}

1. Perlu dilakukan identifikasi lebih lanjut secara molekuler dan uji serta analisis kandungan asam organik yang dihasilkan oleh kapang yang ditemukan, agar dapat diketahui secara rinci penyebab terjadinya biodeteriorasi pada batuan Candi Borobudur.

2. Perlu dilakukan penelitian lebih lanjut mengenai cara menghambat pertumbuhan kapang kontaminan pada batuan Candi dan upaya meminimalisir kerusakan batuan candi dengan pembersihan secara rutin.

\section{UCAPAN TERIMA KASIH}

Terima kasih penulis ucapkan kepada Nahar Cahyandaru M. Sc dan Dr. Dra. Bernadetta Octavia, M.Si selaku pembimbing penelitian ini yang telah memberikan banyak sumbangsih ilmu, saran, bimbingan dan arahan pada penulis.

\section{DAFTAR PUSTAKA}

Barnett, H. L \& B. B. Hunter.(1998). Illustrated Genera of Imperfect Fungi Fourth edition. APS Press. The American Phytopathological Society USA. 
Christopher, J. M. \& Mitchell, R. (2005). Microbial deterioration of historic stone. The Ecological Society of America. 3(8): 445-451

Crystovel, Josua. (2016). Mikologi Tanaman: Penicillium, Paecilomyces Aspergillus. Universitas Padjadjaran Sumedang

David, E., Stephen, D., Helen, A., Rosemary, H dan Robyn, B. (2007). Descriptions Of Medical Fungi, Second edition. Australia : University Of Adelaide

Efa, R., Riza., Siti, K. (2014). Kapang pada tingkat kematangan gambut yang berbeda di kawasan Hutan Lindung Gunung Ambawang Kabupaten Kubu Raya : Jurnal Protobiont. 3 (3) : $10-16$

Farooq, M., Mukhtiar, H., \& Farzana, G. (2015). Mycobial deterioration of stone monuments of Dharmarajika, Taxila : Journal of Microbiology \& Experimentation, 2.

Habibi, Moh. (2020). Organisme Pelapuk Cagar Budaya dan Aplikasi Minyak Atsiri. Diskusi Daring. Balai Konservasi Borobudur.

Harbowo, D. G. (2011). Proses Pembentukan Biopatina Pada Batuan. Jurnal Konservasi Cagar Budaya. 5(5):20-24. https://doi.org/10.33374/jurnalkonservasicagarbudaya.v5i1.84

Herlinawati, C. (2014). Upaya UNESCO dalam Pelestarian Candi Borobudur sebagai Situs Warisan Dunia Pasca Erupsi Gunung Merapi Tahun 2010. Ejournal Ilmu Hubungan Internasional, 2 (1), pp.171-182

Indrawati, G., Robert, A. S., Karin Van, D. T., Ariyanti, O., Iman, S. (1999). Pengenalan Kapang Tropik Umum. DKI jakarta : Yayasan Obot Indonesia

Leliek, A. H., Rony, M. \& Al. Widyo, P. (2014). Karakteristik Batu Penyusun Candi Borobudur : Jurnal Konservasi Cagar Budaya Borobudur. Balai Konservasi Borobudur, 8 (1), 38-47. https://doi.org/10.33374/jurnalkonservasicagarbudaya.v8i1.123

Parisa, M \& Nasim, M, B. (2014). Isolation and molecular identification of deteriorating fungi from Cyrus the Great tomb stones : Iranian Journal of Microbiology, 6 (5), $361-370$.

Nabiilah, A.F \& Dina, A.S.P (2016). Isolasi Jamur dari Batuan Penutup Drainase Pada Sisi Selatan Lantai II Bidang H Candi Borobudur. Jurnal Konservasi Cagar Budaya Borobudur, 10 (2), 40-44

Riadi, Imam. (2020). Deteksi dan Identifikasi Kapang pada Proses Biodetertiorasi Arsip Foto Memory of The World (MOW) Restorasi Candi Borobudur. Tugas Akhir Skripsi. Universitas Negeri Yogyakarta

Sanjay, P.G \& Kavita, S. (2011). Biodeterioration And Preservation Of Sita Devi Temple, Deorbija, Chhattisgarh, India. InternationalJournal Of Conservation Science, 2, 89 -94 . 
Siregar, I. M. (2011). Identifikasi kerusakan dan Pelapukan Batuan. Makalah; disajikan dalam Pelatihan Tenaga Teknis Konservasi Tingkat Menengah. Balai Konservasi Borobudur. Magelang, 25 Juli - 13 Agustus 2011.

Sugiyono. (2013). Metode Penelitian Kuantitatif, Kualitatif dan $R \& \&$ D. Bandung : Alfabeta Bandung

Suhartono, Y., Winda, D, P \& Panggah, A. (2018). 10 Tahun Pelestarian Candi Borobudur. Magelang : Balai Konservasi Borobudur

Tikam, C.D \& Swaranjit, S. C.(2012). Microbially induced deterioration of architectural heritages: routes and mechanisms involved. Dakal and Cameotra Environmental Sciences Europe, 24 (36), 1-13

UNESCO Office Jakarta. (2013). Melestarikan Candi Borobudur untuk Masa Depan. Jakarta: UNESCO Office Jakarta

Yanuardi, M, H. (2009). Penyebab Kerusakan Dan pelapukan Beserta Penanganannya: Studi Atas Faktor Biotik dan Abiotik di Candi Borobudur. Jurnal Sejarah Lontar, $6(2)$ 